\title{
Study on Xi Jinping's Governance Strategy of Xinjiang under the Global Vision
}

\author{
Lei $\mathrm{Wu}$ \\ Marxism College \\ Xinjiang University \\ Urumqi, Xinjiang, China
}

\begin{abstract}
Since general secretary Xi Jinping has been in power, he has put forward a series of new ideas, new ideas and new judgment to examine and grasp the work of Xinjiang in a broad strategic vision. It is, further researching and analyzing the great significance, core content and theory characteristic of $\mathrm{Xi}$ jinping governance strategy of Xinjiang, and to enhance the theory consciousness and conscious action, the realistic need and inevitable requirement of Xinjiang social stability and national security strategy.
\end{abstract}

Keywords-Xi Jinping; governance strategy of Xinjiang; theory characteristic

\section{INTRODUCTION}

Since the Eighteenth National Congress of the Communist Party of China, General Secretary Xi Jinping pays high attention to Xinjiang work, regards Xinjiang problem as a big event for "stabilizing northwest, planning southeast", and repeatedly researches and arranges the Xinjiang work through special investigation, written instructions and approval, the CPC Political Bureau conference and the second central forum on Xinjiang's government work, and other ways, to form the ideas of Xinjiang's governance with distinctive features.

\section{THE STRATEGIC BACKGROUND OF XI JINPING RAISING THE GOVERNANCE STRATEGY OF XINJIANG}

Governance Strategy of Xinjiang is the important principle, policy, strategy, and concept that is used by the central government to govern Xinjiang in different periods. As Xi Jinping's governance strategy of Xinjiang, since General Secretary Xi Jinping is in office, he scientifically analyzes Xinjiang work's complicated situation and tasks, deeply researches Xinjiang work's important theory and the problems in reality, to gradually form the important strategy judgment of governing Xinjiang, stabilizing Xinjiang, building Xinjiang, realizing stable society and long term peace in order, and to achieve target orientation, principle and policy, tactic concept and significant decision making. It not only inherits and

Fund project: This paper is the staged achievement of youth fund project of humanities and social science research of the Ministry of education,

"Research on Spreading of Religious Extremism in Xinjiang and 'Extremism Removal"'(Project No.: 15XJC710003), philosophy and social science research planning fund projects of the Xinjiang Uygur Autonomous Region, Research on Mass Work in Anti-terrorist and Safeguard Stability in Xinjiang (Project No.: 14BKS008), Research on Anti-separation and Anti-infiltration Education in Colleges of Xinjiang (Project No.: 12AKS002) develops the thought of central leaders for collective governance of Xinjiang, but also makes a breakthrough and innovation.

\section{A. The Intrinsic Requirements to Realize the Target of Fully Building A Moderately Well-off Society}

The Eighteenth National Congress of the Communist Party of China clearly pointed out to complete the process of building a moderately well-off society in all aspects till year 2020. Border areas and race regions are the key points for realizing this target. Xinjiang faces many difficulties and challenges such as stability, anti-terrorist, development and religion management during this process, but synchronous access to well-off life with national citizens is popularly supported, in accordance with general trends, and it is the certain results of Xinjiang's development and progress, and also the general trend of country. The Party Central Committee with $\mathrm{Xi}$ Jinping as the core, considers the situation, from country development and safety and stability, to raise a series of new ideas and new judgment about governing Xinjiang, which is strategic consideration of stabilizing and governing border areas, and also the object needs for completing the full construction of well-off society.

\section{B. The Strategic Requirements of "Stabilizing Northwest, Planning to Govern Southeast"}

Our country has had the problems of "coast defense" and "border defense" since the late Qing Dynasty. History has proved that our country's largest threat in national unity and safety comes from border areas, the most unsafe places are mainly in southeast coastal areas and western borderland. Till now, our country still faces the similar difficult, but the situation is a little different. Xinjiang's west place closes to middle Asia, faces "three forces" threat for a long time, and the terrorist activities has a spread trend, even though Xinjiang safety and stability can be controlled generally, the threat is still existing. Southeastern territorial sovereignty and strategy space suffers from neighbor country's erosion for no reason and American restraint of "Back to Asia-Pacific" strategy, and the conflict risk always exists. Therefore, General Secretary Xi Jinping's strategic arrangement about governing Xinjiang, stabling Xinjiang and building Xinjiang is favor of saving energy and time for our country to plan southeast development, which is very significant to country safety. 


\section{The Important Support to Implement "One Belt One Road" Strategy}

In 2013, based on our country's economic development stage requirements and global connectivity development trend, Xi Jinping raised "one belt one road" strategy, which is the national top strategy of our country to actively implement comprehensive open-up, actively seek market and cooperation, take part in global discourse system construction, and has important meaning for both China and the world. As "Silk Roads Economic Belt" construction's core area, Xinjiang should quickly build the five centers of regional transportation junction, commerce and trade and logistics, finance, culture, science and education, medical service. "One belt one road" makes Xinjiang become "leading edge" from "ending edge" in traditional opening pattern, and brings it with very rare strategic opportunity and policy bonus. This comes up with higher requirements for Xinjiang's modernization, whether Xinjiang can realize effective governance largely influences and decides the construction of Silk Road core area and the promotion "one belt one road" strategy.

\section{THE CORE CONTENT OF GOVERNANCE STRATEGY OF XINJIANG BY XI JINPING}

Since General Secretary Xi Jinping was in office, from strategic view analyzes and controls Xinjiang work, plans it, and comes up with a series of new ideas, new opinions, and new judgments, and forms Xinjiang strategy with rich content and comprehensive system.

\section{A. Xinjiang Governance Target: Social Stability and Long- Term Peace and Order}

Xinjiang problem with many contradictions background is not the development problem, or race, religion problem, its essence is split and anti-split problem. Economic development is important, but it doesn't certainly bring social stability, or eliminate national splittism or religion extremism. We can say, only depending on development cannot completely solve Xinjiang social stability and long-term peace and order, or eradicate "three forces" split and destructive activity. In May of 2014, through deeply research, Xi Jinping combined Xinjiang Situation and national situation and made the significant strategic judgment of "social stability and longterm peace and order, are Xinjiang work's general goals", realized the target change from "great-leap-forward development" to "social stability and long-term peace and order", and further made clear Xinjiang work's starting point and strength point. Emphasizing stability, does not mean "not develop", it is emphasizing participatory, inclusive, and confluent development with the stability as the base, use development to stabilize the foundation, and finally realize social stability and long-term peace and order. Aim at domestic and overseas some "noises" about CPC's Xinjiang governance policy", Xi Jinping takes a clear-cut stand and points out that: "practice has proved that, our party's Xinjiang strategy is right, and it should be insisted for long time, keep the strategy's strength [1], and stabilize the target and policy direction.

\section{B. Xinjiang Governance Opinion: Govern Xinjiang According to Law, Stabilize Xinjiang Unity, Build Xinjiang for a Long Time}

"Establish a country with strategy, the country will change from dangerous state to safe state; education and care can make a country peaceful and flourishing" [2]. Xinjiang governance is a long-term, large and complicate systematic engineering, for which top-level design must be followed. General Secretary Xi Jinping focuses on the overall situation of CPC and national career development and the Xinjiang's complicated and special fact, comes up with the opinion of "Govern Xinjiang according to law, stabilize Xinjiang unity, build Xinjiang for long-term", deeply and exactly catches the "root" and "soul" of Xinjiang governance, further makes clear the method, way and emphasis of governing Xinjiang, stabilizing Xinjiang and building Xinjiang, which is the overall strategy and long-term approach to Xinjiang work. History and practice has proved that, rule of law is the most efficient method to solve race and religion's problem, and it is a good approach to Xinjiang governance. The fundamental way to beat violence and terrorism, maintain stability, promote unity and religion management, and "eliminate extremalization" is rule by law. Unity is good, split is bad; unity will benefit all, split will make every party suffer. At present, we should highly open market environment and realize the new situation and new features of race relationship, which brings us larger challenges for good race unity work, and requires us to do more work to stabilize Xinjiang such as giving them enthusiasm and warm, making them admire, agree and associate with us". Xinjiang problem is the mixing of history problem and existing problem, and the solution of Xinjiang problem cannot be anxious for success, it will not be accomplished in an action. It requires us to firmly establish the opinion of "build Xinjiang for a long term" to promote Xinjiang governance and ability, and taking governance system modernization as guide, to accumulate small success for a huge success, and look for recent success for further success.

\section{The Core of Xinjiang Governance: Build Firm Interest Community}

Marx pointed out "everything that people fight for is related to their interests". In the second Xinjiang work symposium of the central government, General Secretary Xi Jinping listed the task of earnestly supporting Xinjiang into the national strategy and national unity construction, which has profound and lasting strategic importance, making Xinjiang development and stability work more closely and directly integrated into the trend of the great rejuvenation of the Chinese nation, and creating people's common happy home for all nations. In fact, we should change the interest relationship by change of interest structure, only by which we can fundamentally change the interest demand and the group relationship, in order to change the interests of the needs and groups. "To solve the problem of Xinjiang, we must keep pace with the times to build a scientific and rational structure of interests to change the relative closure of Xinjiang traditional interest pattern, so as to make Xinjiang and the Mainland to achieve universal and close personnel exchange" [3], and strive to build a solid community of interests. Only by this 
way, Xinjiang's national unity and social stability will have a solid guarantee and benefit support.

\section{Key Point of Governing Xinjiang: Promote National Unity, Suppress Religious Extremism}

National unity is Xinjiang people's lifeline of all ethnic groups, and also the base of Xinjiang development and progress. Xi Jinping pointed out that the most difficult and long-term one for Xinjiang problem was national unity, and we should "focus on the promotion of national unity and the suppression of religious extremism", to do "six interactions" (understanding, respect, toleration, appreciation, study and help), and he further expounded the significance, basic principle and important measures to do well national unity work. In consideration of worldwide extremism ideological trend and religious extremism permeation, Xi Jinping clearly pointed out to take suppression of extremism as one of basic principles in new period to manage religious problem, enrich and develop the party's Marxism religious policy and Xinjiang policy. The facts proved that, fundamental road of race region development is modernization, and religion is one part of reality life, not all. "If a race cannot make their religion quickly adapt to modern society, but still keep traditional outdated things, or even think religion is equal to race itself, then religious beliefs' extremism always leads to race members' parochialism and blinding rejection of foreign things" [4]. Especially in globalization era, any races' shut-up, conservation and lag must restrict their development and progress, even ruin race in the future, while toleration, development and innovation will bring races opening, civilization and happiness.

\section{E. Basis of Governing Xinjiang: Economic Development and People's Livelihood Improvement}

Economic development and people's livelihood improvement is the nature of social development, the basis and guarantee of realizing stability, and also the fundamental measure of reinforcing and consolidating the party's ruling root and ruling power. Since the reform and opening-up policy, Xinjiang's economic development and social construction has got historical notable success, but a certain development gap exists between Xinjiang and mainland, south of Xinjiang and north of Xinjiang, all nations, especially small gap exists in the three cities of south Xinjiang for the target requirements of the central government to fully build a well-off society in 2020, and in the poor area to cast off poverty. In the second central government and Xinjiang work symposium, Xi Jinping pointed out that we should "base upon economic development and people's livelihood improvement", "make development implemented in people's livelihood, local place and nation unity" [1]. This idea not only embodies the basic principle of "development is the first" and "people's livelihood prior", and further makes clear the beginning point and ending point of Xinjiang governance, which can help us handle well the relationship between development and people's livelihood and between people's livelihood and stability, realize the good interaction between development and stabilization, and continuously enhance the internal power and foundation of Xinjiang social development and stabilization.

\section{F. The Key of Governing Xinjiang: Play the Role of the CPC as Leading Core}

The Communist Party of China is the leading core of the socialism with Chinese characteristics, and it is also the leading core of governing Xinjiang, stabling Xinjiang and building Xinjiang. CPC's over 60-year governance in Xinjiang's practice has proved that: the Communist Party of China's leading is the fundamental guarantee of Xinjiang development and progress. General Secretary Xi Jinping has pointed out: "To do the work of Xinjiang, the key is to play the core leadership of the party in overall situation and coordinate all parties, to strengthen and improve Party's building, provide a strong political guarantee for social stability and long period of stability in Xinjiang" [1]. The core leading role of the party performs in the party organizations at all levels, the key is in primary party organization. Adhere to the leadership of the party, and also pay attention to improve the party's leadership. To adhere to organize the strong team, strengthen the organization's requirements, and strive to build the primary party organization into a stronghold of serving the masses, maintaining stability, and fighting against the strong Separatist.

\section{THE THEORY FEATURES OF XINJIANG GOVERANCE STRATEGY BY XI JINPING}

\section{A. Contain Rich Dialectical Materialism Epistemology}

According to Marx's philosophy, only the scientific method of thinking in the process of understanding can obtain the truth, and make the real knowledge to be tested, enriched and developed in practice. Through scientific analysis of the situation in Xinjiang and of the whole country, Xi Jinping pointed out "the general targets of Xinjiang work is to keep the social stability and long period of peace and stability" that reflected the good trend of strategic thinking; "governing Xinjiang by the rule of law, stabilizing Xinjiang unity, making Xinjiang construction for a long term" showed the comprehensive measures of innovative thinking; the thought of "improving people's livelihood, promoting national unity and combating violence" reflected the integrated dialectical thinking, "promoting Xinjiang's governance system modernization and governance capacity modernization" embodied the modern orientation of scientific thinking. We can see that, Xi Jinping, the General Secretary's important decision on the work of the deployment of Xinjiang comes from practice, but also is higher than practice, contains rich Marxist philosophy of thought, shining the light of dialectical thinking.

\section{B. Reflect the Marxist Mass View}

Marx believes that the masses are the main body of practice and the creators of history. The Communist Party of China has always practiced and adhered to the concept of "development for the people, development relying on the people and the fruits of development shared by the people". This idea has a distinct reflection on the Xinjiang strategy of $\mathrm{Xi}$ Jinping. On the second central forum on Xinjiang work, Xi Jinping put forward that the Xinjiang work should be based on "Xinjiang's economic development and people's livelihood improvement"; the development should be implemented to 
improve the livelihood of the people, and should benefit the local people; we should adhere to the "three cannot-dowithout", promote national unity, maximize the unity of all ethnic groups and the support of the masses, do well people's war on terror; adhere to the "people first", and let every nation, every citizen share the results of the motherland prosperity and development. These statements of $\mathrm{Xi}$ Jinping once again confirmed our serious promise that "the people's yearning for a better life is the goal of our struggle", which embodied the mass view of people oriented.

\section{Embody the "Four Overall" Strategic Thinking}

"The "four overall" strategic layout is the Chinese nation planning and strategic security for the CPC Central Committee with $\mathrm{Xi}$ Jinping as the General Secretary to insist on and develop socialism with Chinese features, make initiative action, solve the ills and problems, and realize the great rejuvenation, which has great significance. At present, the Xinjiang issue is the most typical and representative one in the national governance, which also needs a high-level design and an overall advancement. Xi Jinping's series statements on Xinjiang being constructed into well-off society synchronously with the whole country, promoting the Xinjiang governance capacity and governance system modernization, governing Xinjiang by the rule of law, "comprehensively strengthening and improving Party building, and providing strong political guarantee for the social stability and long period of stability in Xinjiang", are the vivid practice of "four overall" strategic thinking in Xinjiang governance, which also embody the consistency of the central leaderships' core for governance ideas and concepts.

\section{Show the Theoretical Thinking to Adapt to and Grasp the "New Normal"}

In 2014, Xi Jinping put forward the "new normal" theory; in the narrow sense, it refers to the economic field, and in broad sense, it refers to the "new norm" of reality-faced and problem-oriented governance, "not stick to practice, but observant to common sense". In the three superimposed period of Xinjiang, counter-terrorism task is our major responsibility and we have a long way to go, economic development is facing a major strategic opportunity to "One Belt One Road ", the people's hearts are warmed, and the overall situation is becoming good and stable. This is the "new normal" of Xinjiang social governance. It urgently needs the person in power to "seek long-term strategy, make implementation for consolidation", adhere to the "governing Xinjiang by rule of law, promoting Xinjiang unity and stability, making a longterm construction for Xinjiang", and further to adapt to the new normal and show new achievements.

\section{CONCLUSION}

At present, facing and solving Xinjiang problem, we must have the international perspective, the overall situation thinking, maintain strategic concentration and stability of Xinjiang governance, uphold and improve the party's governing strategy of Xinxiang. To adapt to the new normal situation, we should grasp the new normal situation, promote the modernization of governance systems and governance capacity of Xinjiang, then strengthen the consciousness and initiative in the implementation of central strategy on Xinjiang governance, and ensure to achieve the overall goal of Xinjiang social stability and national overall strategy security.

\section{REFERENCES}

[1] Xinhua News Agency, Xi Jinping delivered an important speech at the second central Xinjiang Work Forum [EB/OL]. http://news.xinhuanet.com/photo/2014-05/29/c_126564529.htm,2014-529.

[2] Lv Buwei: Lvshi history.Youshilan.yuda, Tiayuan: Shuhai Press

[3] Li Xuejun, long-term building Xinjiang problem research in the background of new normal situation[J], Xinjiang Social Science Forum. 2015,(1):55.

[4] Xu Zhiyong, to become a firm political party members and cadres in Xinjiang $\quad[\mathrm{EB} / \mathrm{OL}]$. http://www.qstheory.cn/laigao/201405/23/c_1110824473.htm,2014-5-23. 